\title{
Recombinant Human Erythropoietin: Manfaat dalam Bidang Kedokteran
}

\section{Recombinant Human Erythropoietin: Benefits in Veterinary Medicine}

\author{
Yanuartono, Hary Purnamaningsih, Alfarisa Nururrozi, Soedarmanto Indarjulianto*, Slamet Raharjo \\ Departemen Ilmu Penyakit Dalam, Fakultas Kedokteran Hewan Universitas Gadjah Mada. \\ Jl. Fauna No.2, Karangmalang, Depok, Sleman. 55281 Yogyakarta \\ *Email: indarjulianto@ugm.ac.id
}

Naskah diterima : 22 Januari 2019, direvisi : 2 Mei 2019, disetujui : 30 Mei 2019

\begin{abstract}
Recombinant human erythropoietin (rhEPO) is one of the biotechnology-based drugs that are needed by the human medicine and has also been used in the veterinary medicine. Currently RhEPO has been widely used in the world of human medicine for the treatment of anaemia caused by renal failure, cancer, chronic inflammation and AIDS. In veterinary medicine, although there is still not much data on its achievements, rhEPO has also been used for cases of chronic renal failure in dogs and cats. However, since rhEPO is not identical to feline EPO and canine EPO, some patients eventually produce antibodies against the drug. The antibodies not only prevent EPO therapy from being effective, but also may lead to severe and life-threatening anemia. This paper provides a review of the use of RhEPO, rfEPO and rcEPO in veterinary medicine, especially for the purpose of non-regenerative anemia therapy in cases of chronic renal failure in dogs and cats.
\end{abstract}

Keywords: anaemia; cat; chronic renal failure; dog; recombinant human erythropoietin

\begin{abstract}
Abstrak
Recombinant human erythropoietin (rhEPO) adalah salah satu obat berbasis bioteknologi yang sangat dibutuhkan dunia kedokteran manusia dan juga telah dimanfaatkan juga dalam dunia kedokteran hewan. Saat ini rhEPO telah digunakan secara luas dalam dunia kedokteran manusia untuk terapi anemia yang disebabkan oleh gagal ginjal, kanker, keradangan kronis dan AIDS. Dalam dunia kedokteran hewan, meskipun masih belum banyak data keberhasilannya, rhEPO juga telah dimanfaatkan untuk pengobatan kasus gagal ginjal akut dan kronis pada anjing dan kucing. Namun, karena rhEPO tidak identik dengan EPO kucing (rfEPO) dan EPO anjing (rcEPO), beberapa hewan menghasilkan antibodi terhadap rhEPO tersebut. Antibodi tidak hanya mencegah terapi EPO menjadi efektif, tetapi juga dapat menyebabkan anemia berat dan mengancam jiwa. Tulisan ini mencoba memberikan ulasan pemanfaatan rhEPO dalam dunia kedokteran hewan terutama untuk tujuan terapi anemia non regeneratif kasus penyakit ginjal kronis pada anjing dan kucing. Dengan ulasan singkat ini diharapkan dunia kedokteran hewan di Indonesia mulai mencoba menggunakan rhEPO rfEPO dan rcEPO untuk tujuan terapi pada hewan kesayangan khususnya anjing dan kucing.
\end{abstract}

Kata kunci: anjing; anemia; gagal ginjal kronis; kucing,; recombinant human erythropoietin

\section{Pendahuluan}

Erythropoietin (EPO) adalah hormon glikoprotein $30,4 \mathrm{kDa}$ yang merupakan regulator utama produksi eritrosit sebagai respon terhadap penurunan oksigenasi pada jaringan (Jelkmann, 2013). Erythropoietin terutama diproduksi oleh sel interstitial peritubular korteks ginjal korteks ginjal (Koury et al., 1988; Eschbach, 1989) dan sebagian kecil oleh hati, meskipun semua sel pada dasarnya memiliki kemampuan mentranskrip gen Epo dalam kondisi hipoksia (Koury et al., 1989). Produksi EPO oleh hati terutama terjadi pada periode janin dan perinatal dan 
Yuartono, et. al.

produksi oleh ginjal mendominasi selama masa dewasa (Ifeanyi and Uzoma, 2016). Kekurangan hormon EPO pada penderita penyakit gagal ginjal kronis menjadi penyebab utama anemia non regeneratif. Menurut Yin and Blanchard (2000) salah satu obat berbasis bioteknologi yang sangat dibutuhkan dunia kedokteran manusia dan juga telah dimanfaatkan juga dalam dunia kedokteran hewan saat ini adalah recombinant human erythropoietin (rhEPO). Epoetin alpha, epoetin beta, epoetin omega dan epoetin delta adalah klasifikasi nama komersial rhEPO yang saat ini sudah tersedia di pasar untuk tujuan terapi (Storring et al., 1998; Skibeli et al., 2001). Klasifikasi didasarkan atas perbedaan struktur kimia dan metode pembuatannya dimana perbedaan struktur kimia terdapat pada kadar oligosakarida. Epoetin alfa (39\% oligosakarida), epoetin beta (24\% oligosakarida), dan epoetin omega (21\% oligosakarida), namun demikian tidak terdapat perbedaan dalam efikasi dan farmakologinya (Loughnan et al., 2011; Fuadi and Bisri, 2015). Berdasarkan metode pembuatannya, epoetin alpha dan epoetin beta disintesis dari ovarian cells of Chinese hamster (CHO), sedangkan epoetin omega disintesis dari sel sel ginjal hamster (BHK) (Choi et al., 1996). Saat ini rhEPO telah digunakan secara luas dalam dunia kedokteran manusia untuk terapi anemia yang disebabkan oleh gagal ginjal, kanker, keradangan kronis dan AIDS (Goodnough et al., 2000; Jelkmann, 2000; Bron et al., 2001; Conley et al., 2009). Recombinant human erythropoietin telah dibuat dari berbagai sumber seperti bakteri (Huang, 1984), kultur sel mamalia (Goto et al.,1988), sel serangga (Kim et al., 2005), susu kambing transgenik (Toledo et al., 2006) dan ragi (Hamilton et al., 2006). Recombinant Human erythropoietin (rhEPO) sudah digunakan dalam pengobatan klinik pada pasien manusia penderita anemia, khususnya disebabkan oleh gagal ginjal pada sejak tahun 1988. Sampai saat ini rhEPO yang digunakan secara luas untuk terapi adalah berasal dari kultur sel mamalia meskipun teknis pembuatanya lebih kompleks dan memerlukan biaya yang tinggi. Meskipun demikian, menurut (Hoeksema (2011) dan Surabattula et al. (2011) produksi rhEPO masih perlu penelitian lebih mendalam untuk mengoptimalkan penggunaan peran rhEPO dalam dunia kedokteran, baik manusia maupun hewan.

Recombinant human erythropoietin telah banyak dimanfaatkan untuk berbagai macam kepentingan seperti penelitian dampak rhEPO pada hewan coba dan untuk terapi anemia non regeneratif pada penyakit gagal ginjal kronis. Penelitian dampak rhEPO telah dilakukan dengan hewan coba tikus (Sadamoto et al., 1998; Shi et al., 2013), mencit (Bernaudin et al., 1999; Rodrigue et al., 2008), macaques (Gao et al., 2004). Dalam dunia kedokteran hewan, meskipun masih belum banyak data keberhasilannya, rhEPO juga telah dimanfaatkan untuk pengobatan kasus gagal ginjal akut dan kronis pada anjing dan kucing (Randolph et al., 2004; Langston et al., 2017). Tulisan ini mencoba memberikan ulasan pemanfaatan rhEPO dalam dunia kedokteran hewan terutama untuk tujuan terapi anemia non regeneratif kasus penyakit ginjal kronis pada anjing dan kucing. Dengan ulasan singkat ini diharapkan dunia kedokteran hewan mulai mencoba menggunakan rhEPO untuk tujuan terapi pada hewan kesayangan khususnya anjing dan kucing.

\section{Struktur dan Fungsi rhEPO}

Eritropoietin atau disebut juga hematopoietin atau hemopoietin adalah hormon glikoprotein dengan berat molekul 30-39 $\mathrm{Kd}$ yang dihasilkan oleh sel peritubular ginjal untuk menstimulasi sumsum tulang agar melakukan proses eritropoiesis, juga berperan 
dalam proses proliferasi, maturasi, dan pelepasan retikulosit (Coleman and Brines, 2004). Gen eritropoietin manusia terletak di kromosom 7q11-22, tersusun atas lima akson dan empat intron, yang menghasilkan tulang punggung polipeptida tunggal pasca-transkripsional dan mengandung 193 asam amino (law et al., 1986; Eschbach et al., 1987; Jelkmann, 1992). Namun, selama modifikasi pascatranslasional terjadi pemecahan asam-asam amino di 27 N-terminal dan arginin C-terminal sehingga struktur Epo akhirnya hanya mengandung 136 asam amino (Imai et al., 1990). Recombinant human erythropoietin (rhEPO) adalah hasil rekayasa genetik (recombinant DNA technology) yang identik eritropoietin endogen dan mengandung protein kecil yang tersusun dari 165 amino acid glycoprotein dengan berat molekul 30.000 Dalton (Egrie, 1990; Inoue et al., 1995). Recombinant human erythropoietin mempunyai sifat biologis dan kimia yang sama dengan eritropoietin endogen (Jacobs et al., 1985; Eder et al., 1989). Faktor yang membedakan antara bentuk rekombinan dan eritropoietin endogen adalah pada pola glikosilasi dari bentuk rekombinan lebih besar, sehingga aktivitas biologis in vivo eritropoietin endogen (70.000 IU/mg) lebih rendah daripada eritropoietin rekombinan (200.000 IU/mg). Rantai glikosilasi rHEPO memiliki peran penting dalam hal biosintesis, struktur molekul dan aktivitas biologis (Elliott et al., 2008).

Penelitian-penelitian awal menunjukkan bahwa secara in vivo keberadaan glikosilasi sangat esensial agar EPO dapat menjalankan fungsinya dengan baik (Browne et al., 1986; Egrie et al., 1986). Sedangkan secara in vitro, glikosilasi tidak berpengaruh terhadap fungsi dan kinerja EPO. Studi lain menunjukkan bahwa ada hubungan yang erat antara glikosilasi pada rhEPO dengan waktu paruhnya (half-life) di mana dengan semakin meningkatnya kandungan asam sialat waktu paruh dan aktivitas biologi in vivo juga akan meningkat. Hal ini mengindikasikan bahwa molekul hEPO dengan kandungan asam sialat yang tinggi akan mempunyai aktivitas biologis yang lebih baik (Delorme et al., 1992; Egrie and Browne 2001). Sebaliknya, derajat glikosilasi tidak berpengaruh pada kemampuan klinisnya, meskipun jumlah glikosilasi akan berpengaruh pada frekuensi pemberiannya (Storring et al., 1998; Langston et al., 2003)

\section{Penggunaan rhEPO Dalam Dunia Kedokteran}

Selama dua dekade terakhir dalam dunia kedokteran manusia, rhEPO menjadi terapi standar dalam penyembuhan anemia kronis (Jelkmann, 2008) dan penderita gagal ginjal kronis (Tamadon and Beladi-Mousavi, 2013) penderita kanker (Kumar et al., 2017), AIDS (Ifudu et al., 1997) dan rhematoid arthritis (Peeters et al., 1999). Penelitian aktivitas rhEPO telah banyak dilakukan dengan menggunakan kultur sel berdasarkan berbagai macam cell lines seperti Erythropoietin-dependent human leukemia (AS-E2), human erythroleukaemia TF1, dan megakaryocytic cell line UT-7 (Miyazaki et al., 1997; Qiu et al., 1998). Namun, uji tersebut adalah in vitro sehingga memiliki kelemahan karena tidak mampu membedakan antara EPO utuh dengan varian asialo atau aglikosilasinya yang kebanyakan memiliki waktu paruh lebih pendek sehingga bioaktivitasnya sangat menurun bila diberikan in vivo (Barth et al., 2008).

Penelitian-penelitian penggunaan rhEPO dengan melibatkan berbagai macam hewan coba sebagai model juga telah banyak juga dilakukan. Penggunaan hewan model untuk mengetahui potensi rhEPO pada awalnya dilakukan pada tikus dan mencit dengan mengikuti perkembangan dan perubahan beberapa parameter seperti hematokrit, volume sel darah merah dan jumlah retikulosit (Eder et al., 1989; 
Yuartono, et. al.

Choi et al., 1996). Garrido et al. (2010) melakukan penelitian dengan menggunakan hewan model tikus wistar jantan penderita penyakit ginjal kronis moderat untuk mengetahui kemampuan rhEPO melindungi ginjal, dampak keradangan dan stress oksidatif. Hasil penelitian menunjukkan bahwa rhEPO mampu memperbaiki kondisi anemia, menurunkan tekanan darah dan menurunkan dampak merusak akibat stress oksidatif yang muncul pada penyakit ginjal kronis moderat. Hasil penelitian oleh Bernado et al. (2016) menunjukkan bahwa pemberian rhEPO pada tikus Sprague-Dawley terbukti meningkatkan proses penyembuhan fraktur tulang mandibula yang ditandai dengan peningkatan osteoblastogenesis dan osteoklastogenesis yang tampak dari peningkatan jumlah osteoblas dan osteoklas. Ramakrishnan et al. (2003) telah melakukan penelitian pengaruh pemberian rhEPO terhadap farmakodinamik dan farmakokinetik retikulosit, sel darah merah dan $\mathrm{Hb}$ pada Cynomolgus Monkeys. Hasil penelitiannya menunjukkan bahwa Cynomolgus Monkeys dapat digunakan sebagai hewan model farmakodinamik dan farmakokinetik rhEPO. Studi menggunakan hewan coba tikus Sprague Dawley yang diinjeksi menggunakan rhEPO dapat mempercepat proses re epitelialisasi dan penyembuhan luka yang disebabkan oleh luka bakar dermis dalam (Sandhi, 2015). Hasil penelitian penelitian in vitro maupun in vivo dengan menggunakan hewan model tersebut menekankan arti penting upaya lanjut untuk meningkatkan dan menyempurnakan metodologi penggunaan rhEPO yang telah ada sehingga hasilnya dapat diimplementasikan untuk kepentingan medis dalam dunia kedokteran manusia maupun hewan.

\section{Terapi Anemia Anjing dan Kucing Menggunakan rhEPO.}

Dalam dunia kedokteran hewan rhEPO juga telah dimanfaatkan untuk pengobatan kasus gagal ginjal akut dan kronis pada anjing dan kucing (Boran et al., 1993). Menurut Bugelski et al. (2008), human EPO secara biologis menjadi aktif ketika diberikan kepada hewan dan pemberian human EPO akan memperbaiki kondisi anemia karena defisiensi EPO pada anjing nefrektomi (Oishi et al., 1995). Pada kucing dan anjing, salah satu gejala klinis progresif terkait dengan gagal ginjal kronis adalah anemia non regeneratif. Hasil penelitian pada manusia juga menunjukkan bahwa kasus gagal ginjal kronis disertai anemia non regeneratif memiliki angka konsentrasi serum eritropoietin yang rendah (Andrews et al., 2014). Recombinant human erythropoietin sebenarnya tidak direkomendasikan untuk digunakan pada hewan kesayangan seperti anjing dan kucing, oleh sebab itu pemilik wajib untuk menandatangani dokumen kesediaan untuk penggunaan pada hewannya. Sebelum diberikan, perlu dipertimbangkan potensi munculnya reaksi yang merugikan pada pasien gagal ginjal kronis dengan tanda-tanda klinis yang disebabkan anemia sebelum terapi rhEPO diberikan (Langston et al., 2003). Anemia non regeneratif merupakan konsekuensi penyakit gagal ginjal kronis yang tidak dapat dihindari meskipun ada beberapa faktor lain yang turut berperan seperti penurunan life span eritrosit dan perdarahan gastrointestinal. Meskipun demikian, penyebab paling dominan pada kejadian anemia non regeneratif pada anjing penderita penyakit gagal ginjal kronis adalah berkurangnya produksi EPO dari ginjal (King et al., 1992). Sanderson (2005) menambahkan bahwa rhEPO adalah pengobatan pilihan untuk kondisi anemia yang tidak mengancam jiwa pada anjing dan kucing penderita gagal ginjal kronis. Terapi tersebut dianjurkan jika gejala klinis anemia mulai muncul dan pemeriksaan laboratoris menunjukkan nilai hematokrit turun di bawah $20 \%$.

Henry (1994) menggunakan rhEPO untuk 
terapi kucing penderita gagal ginjal kronis dengan status anemia. Dosis yang digunakan adalah 100U/kg BB subkutan 3 kali seminggu, setelah 10 hari pengobatan memberikan hasil peningkatan, hematokrit mengalami peningkatan menjadi 0,31 dari sebelumnya 0,16. Cowgill et al., (1998) melakukan pengujian efikasi dan keamanan rhEPO secara intravena dan subkutan pada 6 ekor anjing dan dan 11 ekor kucing penderita gagal ginjal kronis. Terapi tersebut mampu meningkatkan jumlah sel darah merah (SDM), retikulosit dan konsentrasi $\mathrm{Hb}$. Hasil pemeriksaan secara klinis juga menunjukkan adanya variasi peningkatan nafsu makan, berat badan, kewaspadaan dan kemauan untuk bermain. Meskipun demikian, terapi tersebut juga menimbulkan efek samping yang beragam dan tidak konsisten. Efek samping yang sering muncul adalah anemia, peningkatan antibodi anti-rhEPO, kejang, hipertensi sistemik dan defisiensi zat besi. Hasil penelitian maupun studi kasus terdahulu menunjukkan bahwa pemberian rhEPO pada anjing dengan status anemia non regeneratif sekunder akibat penyakit ginjal kronis mampu menginduksi respon eritrosit secara cepat. Namun sayangnya, beberapa anjing yang dirawat memperlihatkan respon positif singkat sebelum akhirnya mati karena munculnya antibodi terhadap rhEPO (Mikiciuk et al., 1990; Cowgill, 1991; Giger, 1992; Langston et al., 2003). Penelitian oleh Fiocchi et al. (2017) menunjukkan beberapa efek samping yang muncul setelah pemberian Darbepoetin alfa pada anjing penderita penyakit ginjal kronis. Efek samping paling banyak ditemukan adalah peningkatan tekanan darah sistolik. Dua puluh lima anjing yang diperiksa tekanan darahnya, 24 anjing mengalami peningkatan tekanan darah sistolik dan efek samping pada gastrointestinal yang berupa diare ditemukan pada 1 anjing. Efek samping tersebut hanya berlangsung satu hari setelah pengobatan. Sanderson (2005) menyarankan untuk melakukan evaluasi tekanan darah pada pasien sebelum memulai terapi r-HuEPO. Pemantauan dan terapi tekanan darah sistemik harus dilakukan jika tekanan darah kucing meningkat dan dosis yang diberikan harus diturunkan untuk untuk mencegah peningkatan tekanan darah yang cepat.

Studi kasus yang lain menunjukkan bahwa pada beberapa pasien, kondisi anemia menjadi lebih buruk dibandingkan dengan sebelum terapi dengan menggunakan rhEPO. Menurut Wen et al. (1993), aktivitas biologis erythropoietin antara anjing, kucing dan manusia menunjukkan kemiripan karena $85 \%$ homolog dengan erythropoietin manusia. Meskipun aktivitas biologis EPO dari spesies mamalia lain seperti anjing dan kucing mirip dengan EPO manusia, namun ada perbedaan antigenik spesies-spesifik. Perbedaan antigenik spesies-spesifik tersebut kemungkinan akan mengakibatkan pembentukan antibodi anti-EPO. Selain hal tersebut, perbedaan antigenik spesies-spesifik diduga akan menimbulkan masalah dalam ketepatan menentukan kadar serum erythropoietin anjing atau kucing karena menggunakan erythropoietin manusia sebagai dasar uji (Giger, 1991). Pendapat tersebut didukung oleh MacLeod et al. (1998) yang membuktikan bahwa ada sekitar 18,7\% perbedaan sekuens asam amino primer antara rhEPO dengan recombinant canine erythropoietin (rcEPO) sehingga berpotensi meningkatkan antibodi terhadap EPO. Lebih lanjut MacLeod, (2001) menambahkan bahwa dengan adanya berbagai macam variasi dalam struktur molekul erythropoietin pada anjing dan kucing untuk dapat mengenali rhEPO sehingga berdampak pada peningkatan antibodi terhadap rhEPO. Antibodi yang diproduksi oleh kucing dan anjing setelah pengobatan dengan rhEPO tidak hanya memblokir aktivitas rhEPO, tetapi juga mungkin memiliki potensi untuk mengenal reaksi silang erythropoietin endogen, yang 
dapat menyebabkan gangguan pada sumsum tulang dan disebut dengan aplasia sel darah merah. Sanderson (2005) menyatakan bahwa pembentukan antibodi diperkirakan terjadi pada sekitar 50\% anjing dan kucing yang menerima terapi rhEPO. Pembentukan antibodi tersebut memiliki kecenderungan terjadi dalam waktu sekitar 1 sampai 6 bulan setelah terapi rhEPO dimulai. Respon antibodi yang dapat bertahan lama tersebut membuat hewan memerlukan trnasfusi darah untuk mencegah kondisi anemia dan berakibat pada tingginya pengambilan keputusan euthanasia pada hewan terdampak (Chalhoub et al., 2011; Chew et al., 2011).

Cowgill et al. (1998) menemukan hasil yang menarik karena setelah 4 minggu terapi rhEPO anjing mengalami hipoplasia eritroid, meskipun produksi sel darah merah pulih 5 hingga 11 minggu setelah terapi rhEPO dihentikan. Oleh sebab itu, pemberian rhEPO pada anjing masih memerlukan pertimbangan dari sisi manfaat maupun risiko sebelum tersedianya bentuk erythropoietin rekombinan yang homolog. Hasil penelitian Chalhoub et al. (2012) menunjukkan bahwa pemberian darbepoetin pada kucing penderita penyakit ginjal kronis mampu merangsang eritropoiesis dan membantu memperbaiki kondisi anemia. Dosis awal $1,0 \mu \mathrm{g} / \mathrm{kg}$ SC sekali seminggu tampaknya memberikan respons yang lebih baik daripada dosis yang lebih rendah, dan suplementasi preparat $\mathrm{Fe}$ sangat dianjurkan selama pengobatan darbepoetin karena merupakan komponen penting pembentukan hemoglobin. Pemberian rhEPO tanpa disertai dengan pemberian preparat $\mathrm{Fe}$ akan memperparah kondisi defisiensi Fe pada hewan penderita (Eschbach et al., 1989; Randolph et al., 1999). Preparat Fe yang dapat digunakan adalah Ferrous sulfate per oral dengan dosis 100-300 mg/hari untuk anjing, sedangkan untuk kucing dosis yang dianjurkan adalah 50-100 mg/hari (Langston et al., 2003). Jika hewan dalam kondisi muntah akibat pemberian preparat Fe peroral maka dianjurkan untuk menggunakan $F e$ dextran intramuskuler dengan dosis $10-20 \mathrm{mg} / \mathrm{kg}$ untuk anjing dan total $50 \mathrm{mg} /$ ekor kucing setiap bulan. Sebaliknya Henry (1994) menyatakan tidak perlu memberikan suplementasi preparat Fe karena selama pengobatan dengan rhEPO nilai serum $\mathrm{Fe}$, total iron binding capacity (TIBC) dan saturasi transferin masih dalam kisaran normal. Meskipun terjadi perbedaan pendapat, Sanderson (2005) menyarankan evaluasi status Fe sebelum memulai terapi dengan terapi rhEPO. saran tersebut didasarkan pada adanya respon eritropoietik dari rhEPO membutuhkan mobilisasi Fe dalam jumah yang besar dari simpanan jaringan untuk mendukung sintesis hemoglobin. Kegagalan pemberian Fe dalam jumlah yang memadai dapat menyebabkan lemahnya respons terhadap terapi rhEPO atau bahkan tidak ada respon sama sekali.

\section{Terapi Anemia Anjing dan Kucing Menggunakan rfEPO atau rcEPO.}

Konsep penggunaan EPO sampai saat ini tampaknya sudah tepat untuk terapi hewan kesayangan pada kondisi anemia yang disebabkan oleh gagal ginjal kronis. Permasalahan utama dalam penggunaan rhEPO adalah imunogenisitas rhEPO. Penelitian MacLeod et al. (1998) membuktikan bahwa terdapat sekitar 18,7\% perbedaan sekuens asam amino primer antara rhEPO dengan recombinant canine erythropoietin ( $\mathrm{rcEPO})$ sehingga berpotensi meningkatkan respon antibodi terhadap EPO. MacLeod, (2001) menyatakan saat ini telah ada pengembangan penelitian untuk mengatasi adanya berbagai macam variasi dalam struktur molekul erythropoietin antar spesies hewan untuk menekan dampak pada peningkatan tanggap kekebalan terhadapnya. Randolph et al. (1999) melakukan penelitian untuk membandingkan pengaruh pemberian rhEPO dan RcEPO pada 13 anjing sehat. Hasil 
penelitiannya menunjukkan bahwa terapi dengan rcEPO selama kurun waktu 24 minggu mampu menstimulasi produksi eritrosit tanpa satupun anjing yang mengalami hipoplasia erythroid. Penelitian lanjut yang dilakukan oleh Randolph et al. (2004) menunjukkan bahwa recombinant canine erythropoietin (rcEPO) merangsang produksi eritrosit anjing penderita gagal ginjal kronis dengan status anemia dengan periode pengobatan selama 1 tahun tanpa muncul efek samping aplasia sel darah merah seperti terapi dengan menggunakan rhEPO. Selanjutnya dia menyimpulkan bahwa rcEPO dapat menjadi pilihan yang lebih baik untuk terapi anemia non regeneratif pada anjing dibandingkan dengan penggunaan rhEPO, meskipun masih dijumpai beberapa kendala dalam penggunaan rcEPO.

Recombinant human erythropoietin telah digunakan pada kucing untuk memperbaiki kondisi anemia dengan keberhasilan yang beragam. Namun demikian, karena rhEPO tidak identik recombinant feline erythropoietin (rfEPO), beberapa kucing akhirnya menghasilkan antibodi terhadap obat tersebut. Pembentukan antibodi tidak hanya membuat terapi rhEPO menjadi kurang efektif, tetapi juga dapat mengakibatkan anemia menjadi lebih berat serta dapat mengakibatkan kematian kucing. Saat ini Laboratorium Dr. James MacLeod di Cornell University telah mengembangkan metode untuk memproduksi recombinant feline erythropoietin (rfEPO) dalam jumlah yang cukup besar untuk terapi anemia kucing penderita gagal ginjal kronis. Pengembangan produksi rfEPO diharapkan mampu mengatasi kondisi anemia pada kucing penderita gagal ginjal kronis tanpa efek samping yang muncul seperti pada penggunaan rhEPO. Meskipun demikian, munculnya efek samping berupa aplasia sel darah merah juga teramati pada kucing yang diterapi dengan rfEPO. Melihat hasil penggunaan rfEPO dan rhEPO yag kurang optimal untuk terapi pada kucing, Randolph et al. (2004) menyarankan pemberian fEPO melalui terapi gen mungkin merupakan solusi ideal.

Beall et al. (2000) melakukan pengembangan terapi anemia non regeneratif pada kucing penderita gagal ginjal kronis dengan menggunakan recombinant vector containing the feline erythropoietin gene (rAAV/feEpo). Dalam penelitiannya, rAAV/feEpo mampu meningkatkan kadar hematokrit lebih dari 7 minggu setelah injeksi intramuskuler pada kucing sehat. Hasil tersebut tampaknya cukup menjanjikan untuk mengatasi kondisi anemia non regeneratif pada kasus gagal ginjal kronis kucing.

\section{Kesimpulan}

Recombinant human erythropoietin untuk terapi anemia non regeneratif pada kucing dan anjing meskipun masih banyak memiliki kelemahan namun masih menjadi pilihan praktisi dokter hewan. Keuntungan penggunaan rhEPO saat ini lebih ditekankan pada harga yang lebih terjangkau jika dibandingkan dengan rcEPO atau rfEPO serta lebih mudah diperoleh dipasaran. Namun demikian masih diperlukan penelitian untuk meminimalisir dampak negatif yang muncul pada penggunaan rhEPO untuk terapi anemia non regeneratif pada kucing dan anjing. Dimasa mendatang masih diperlukan pengembangan lebih lanjut rfEPO dan rcEPO guna menggantikan peran rhEPO sebagai agen terapi anemia non regeneratif kucing dan anjing. Ketersediaan rfEPO dan rcEPO di masa mendatang mungkin menjadi pilihan pengobatan yang aman dan efektif untuk pasien kucing dan anjing penderita anemia non regeneratif yang terkait dengan gagal ginjal kronis

\section{Daftar Pustaka}

Andrews, D.A., Pyrah, I.T.G., Boren, B.M., Tannehill-Gregg, S.H., And Ruth M. Lightfoot-Dunn, R.M. (2014). High 
Hematocrit Resulting from Administration of Erythropoiesis-stimulating Agents Is Not Fully Predictive of Mortality or Toxicities in Preclinical Species. Toxicologic Pathology, $42: 510-523 . \quad$ D O I : $10.1177 / 0192623313486317$

Barth, T., Oliveira, P.R., Felipe, B., D'avila, F.B. And Dalmora. S.L. (2008). Validation of the NormocythemicMice Bioassay for the Potency Evaluation of Recombinant Human Erythropoietin inmPharmaceutical Formulations. Journal of Aoac International.91 (2): 85-291. http://dx.doi.org/10.1590/S0100879X2003001100014

Beall, C.J., Phipps, A.J., Mathes, L.E., Stromberg, P., And Johnson, P.R. (2000) Transfer of the feline erythropoietin gene to cats using a recombinant adeno-associated virus vector. Gene Therapy 7 (6): 534-539. DOI: 10.1038/sj.gt.3301126

Bernado, P., Rahardjo, And Rahajoe, P.S. (2016). Pengaruh recombinant human Erythropoietin terhadap jumlah osteoblas, osteoklas dan kadar hemoglobin pada penyembuhan fraktur tulang mandibula. Studi eksperimental pada fraktur mandibula tikus Sprague-Dawley. J Ked Gi. 7(2): 131137

Bernaudin, M., Marti, H.H., Roussel, S., Divoux, D., Nouvelot, A., MacKenzie, E.T. And Petit, E. (1999). A potential role for erythropoietin in focal permanent cerebral ischemia in mice. $\mathrm{J}$ Cereb Blood Flow Metab. 19 (6):643-651. DOI:10.1097/00004647-199906000-00007

Boran, M., Dalva, I., Yazicioglu, A., Akbay, E. And Cetin, S. (1993). Correction of anaemia in haemodialysis patients with recombinant human erythropoietin. Int Urol Nephrol 25 (2): 197-203.PMID:8365853

Bron, D., Meuleman, N. And Mascaux, C. (2001). Biological basis of anemia. Semin Oncol 28(2 Suppl 8):1-6. PMID:11395845

Browne, J.K., Cohen, A.M., Egrie, J.C., Lai, P.H., Lin, F.K., Strickland, T., Watson, E. And Stebbing, N. (1986). Erythropoietin: gene cloning, protein structure, and biological properties. Cold Spring Harb Symp Quant B i o 1.51 ( P t 1) : 693-702.
doi:10.1101/SQB.1986.051.01.082

Bugelski, P. J., Nesspor, T., Volk, A., O'Brien, J., Makropoulos, D., Shamberger, K., Fisher, P. W., James, I., Graden, D., And Capocasale, R. J. (2008). Pharmacodynamics of recombinant human erythropoietin in murine bone marrow. Pharm Res 25(2): 369-78. DOI:10.1007/s11095-007-9372-7

Chalhoub, S., Langston, C.E. And Eatroff, A. (2011). Anemia of renal disease. $J$ Fel Med Surg. $13(9): 629-640$. d o i : 10.1016/j.jfms.2011.07.016.

Chalhoub, S., Langston, C.E. and Farrelly, J. (2012). The Use of Darbepoetin to Stimulate Erythropoiesis in Anemia of Chronic Kidney Disease in Cats: 25 Cases. $J$ Vet Intern Med 26 (2):363-369. doi: 10.1111/j.19391676.2011.00864.x

Chew, D.J., DiBartola, S.P., And Schenck, P. (2011). editors. Chronic renal failure. In Canine and Feline Nephrology and Urology. St. Louis, Missouri: Elsevier Saunders.; 145-96.

Choi, D., Kim, M. And Park, J. (1996). Erythropoietin: physico- and biochemical analysis. Journal of Chromatography. 687(1): 189199.https://doi.org/10.1016/S03784347(96)00308-8

Coleman, T. And Brines. M. (2004) Science review: Recombinant human erythropoietin in critical illness: a role beyond anemia? Critical Care 8 (5): 337-341 DOI $10.1186 / \mathrm{cc} 2897)$

Conley, A.J., Mohib, K., Jevnikar, A.M. And Brandle. J.E. (2009). Plant recombinant erythropoietin attenuates inflammatory kidney cell injury. Plant Biotechnology Journal 7(2): 183-199. doi: 10.1111/j.14677652.2008.00389.x

Cowgill, L D., James, K. M., Levy, J. K, Browne, J.K., Miller, A., Lobingier, R.T., And Egrie, J.C. (1998). Use of recombinant human erythropoietin for management of anemia in dogs and cats with renal failure. Journal of the American Veterinary Medical Association 212(4):521-528. PMID:9491159

Cowgill, L.D. (1991). Erythropoietin: Its use in the 
treatment of chronic renal failure in dogs and cats. Proc Annu Waltham/OSU Symp Treat Small Anim Dis. 15:65-71.

Delorme, E., Lorenzini, T., Giffin, J., Martin, F., Jacobsen, F., Boone, T. And Elliott, S. (1992). Role of glycosylation on the secretion and biological activity of erythropoietin. Biochemistry. 31(41): 9871-9876. DOI: 10.1021/bi00156a003

Eder, H., Roblenbroich, B. And Failing, K. (1989). A dose-dependent effect of recombinant erythropoietin on the reticulocyte population of rats. Blut. 59(2): 184-187. PMID:2475191

Egrie, J. (1990). The cloning and production of recombinant human erythropoietin. Pharmacotherapy 10(Pt2):3S-8S. PMID:2345709

Egrie, J.C., Strickland, T.W., Lane, J., Aoki, K., Cohen, A.M., Smalling, R., Trail, G., Lin, F.K., Browne, J.K. And Hines, D.K. (1986). Characterization and biological effects of recombinant human erythropoietin. Immunobiology. 172(3-5):213-24. DOI:10.1016/S0171-2985(86)80101-2

Egrie, J. C. And Browne, J. K. (2001). Development and characterization of novel erythropoiesis stimulating protein (NESP). Br J Cancer. 84 ( $\mathrm{S} \mathrm{u} \mathrm{p} \mathrm{p} 1$ 1 ) : $3-10$. d o i : 10.1054/bjoc.2001.1746

Elliott, S., Pham, E. And Macdougall, I.C. (2008). Erythropoietins: A common mechanism of action. Exp Hematol. 36(12):1573-84. doi: 10.1016/j.exphem.2008.08.003

Eschbach, J.W. (1989). The anemia of chronic renal failure: Pathophysiology and the effects of recombinant erythropoietin. Kidney Int. $35(1): 134-148$. D O I : https://doi.org/10.1038/ki.1989.18

Eschbach, J.W., Egrie, J.C., Downing, M.R., Browne, J.K. And Adamson, J.W. (1987). Correction of the anaemia of end-stage renal disease with recombinant human erythropoietin: results of a combined phase I and II clinical trial. $N$ Engl J Med 316 (2) :73-78. DOI: 10.1056/NEJM198701083160203

Fiocchi, E.H., Cowgill, L.D., Brown, D.C., Markovich, J.E., Tucker, S., Labato, M.A., And Callan,
M.B. (2017). The Use of Darbepoetin to Stimulate Erythropoiesis in the Treatment of Anemia of Chronic Kidney Disease in Dogs. $J$ Vet Intern Med. 31(2):476-485 DOI: $10.1111 /$ jvim. 14681

Fuadi, I. And Bisri, T. (2015). Efek Proteksi Otak Erythropoietin. JNI 4 (2): 149-56

Gao, G., Lebherz, C., Weiner, D.J., Grant, R., Calcedo, R., McCullough, B., Bagg, A., Zhang, Y. And Wilson, J.M. (2004). Erythropoietin gene therapy leads to autoimmune anemia in macaques. Blood. 103 (9): 3300-3302. doi:10.1182/blood-2003-11-3852

Garrido, P., Reis, F., Costa, E., Almeida, A., Parada, B.E., Teixeira-Lemos, E., Santos, P., Alves, R., Sereno, J., Pinto, R., Tavares, C.A., Figueiredo, A., Rocha-Pereira, P., Belo, L., Santos-Silva, A. And Teixeira, F. (2010). Effect of Recombinant Human Erythropoietin in a Rat Model of Moderate Chronic Renal Failure - Focus on Inflammation, Oxidative Stress and Function/Renoprotection. The Open Drug Discovery 22(2) : 25-32. DOI: $10.2174 / 1877381801002020025$

Giger U. (1992). Erythropoietin and its clinical use. Compend Contin Educ Pract Vet 14 :25-34.

Giger, U. (1991). Serum erythropoietin concentrations in polycythemic and anemic dogs. Proc 9th ACVIM Forum:143-145.

Goodnough, L.T., Skikne, B. And Brugnara, C. (2000). Erythropoietin, iron, and erythropoiesis. Blood 96 (3): 823-833. PMID:10910892

Goto, M., Akai, K., Murakami, A., Hashimoto, C., Tsuda, E., Ueda, M., Kawanishi, G., Takahashi, N., Ishimoto, A., Chiba, H. And Sasaki, R. (1988). Production of recombinant human erythropoietin in mammalian cells: host-cell dependency of the biological activity of the cloned glycoprotein. Nature Biotechnology. 6(1): 67-71. DOI: 10.1038/nbt0188-67

Hamilton, S.R., Davidson, R.C., Sethuraman, N., Nett, J.H., Jiang, Y., Rios, S., Bobrowicz, P., Stadheim, T.A., Li, H., Choi, B.K., Hopkins, D., Wischnewski, H., Roser, J., Mitchell, T., Strawbridge, R.R., Hoopes, J., Wildt, S. And 
Yuartono, et. al.

Gerngross, T.U. (2006). Humanization of yeast to produce complex terminally sialylated glycoproteins. Science, 313: 1441-1443. DOI:10.1126/science.1130256

Henry, P. (1994). Human recombinant erythropoietin used to treat a cat with anemia caused by chronic renal failure. Can Vet J. 35(6):375. PMID: 8069840

Hoeksema, F. (2011). Selection markers and expression enhancing elements: Novel strategies to create mammalian production cell lines. Faculty of Science. University of Amsterdam. Thesis Dissertation. Available at: http://dare.uva.nl/document/ 482571

Huang, L.S. (1984). Cloning and expression of human erythropoietin cDNA in Escherichia coli. Proc. Natl. Acad. Sci. USA, 81(9): 27082712. PMID: 6371819

Ifeanyi, O.E. And Uzoma, O.G. (2016). Erythropoietin and Kidney Diseases: A Review. J. Biol. Chem. Research. 33 (2): 760-792

Ifudu, N., Matthew, J.J., Mayers, J.D., Macey, L.J., Brezsnyak, W., Reydel, C., McClendon, E., Surgrue, T., Sreepada Rao, T.K. And Friedman, E.A. (1997). Severity of AIDS and the response to EPO in uremia. American Journal of Kidney Diseases 30 (1): 28-35. DOI: https://doi.org/10.1016/S02726386(97)90561-8

Imai, N., Kawamura, A., Higuci, M., Oh-Eda, M., Orita, T., Kawagchi, T., And Ochi, N. (1990). Physicochemical and Biological Comparison of Recombinant Human Erythropoietin with Human Urinary Erythropoietin1. Journal of Biochemistry $107(3): 352-359$ DOI::10.1093/oxfordjournals.jbchem.a1230 50

Inoue, N., Takeuchi, M., Ohashi, H. And Suzuki, T. (1995) The production of recombinant human erythropoietin. Biotechnol Annu Rev. $1995 \quad(1): 297-313$. https://doi.org/10.1016/S13872656(08)70055-3

Jacobs, K., Shoemaker, C., Rudersdorf, R., Neill, S.D., Kaufmann, R.J., Mufson, A., Seehra, J., Jones, S.S., Hewick, R., And Fritsch, E.F. (1985). Isolation and characterization of genomic and cDNA clones of human erythropoietin. Nature. 313(6005): 806-810. PMID:3838366

Jelkmann, W. (1992). Erythropoietin: structure, control of production and function. Physiol Rev. 72 ( 2 ) : $449-89$. D O I : 10.1152/physrev.1992.72.2.449

Jelkmann, W. (2000). Use of recombinant human erythropoietin as an anti-anemic and performance enhancing drug. Curr Pharmaceut Biotechnol. 1(1):11-31._DOI: https://doi.org/10.2174/1389201003379068

Jelkmann, W. (2008). Developments in the therapeutic use of erythropoiesis stimulating agents. British Journal of Haematology. 141(3): 287-297 doi:10.1111/j.13652141.2007.06948.x

Jelkmann, W. (2013). Physiology and Pharmacology of Erythropoietin. Transfus Med Hemother. 40(5):302-309 DOI: 10.1159/000356193

Kim, Y.K., Shin, H.S., Tomiya, N., Lee, Y.C., Betenbaugh, M.J. And Cha, H.J. (2005). Production and $N$-glycan analysis of secreted human erythropoietin glycoprotein in stably transfected Drosophila $\mathrm{S} 2$ cells. Biotechnol. Bioeng. 92(4): 452-461. DOI: 10.1002/bit.20605

King, L.G., Giger, U., Diserens, D., And Nagode, L.A. (1992). Anemia of chronic renal failure in dogs. J Vet Intern Med. 6 (5): 264-270. PMID: 1432900

Koury, S.T., Koury, M.J., Bondurant, M.C., Caro, J. And Graber, S.E. (1989). Quantitation of erythropoietin-producing cells in kidneys of mice by in situ hybridization: Correlation with hematocrit, renal erythropoietin mRNA, and serum erythropoietin concentration. Blood 74(2): 645-51. PMID: 2752138

Koury, S.T., Bondurant, M.C., And Koury, M.J. (1988). Localization of erythropoietin synthesizing cells in murine kidneys by in situ hybridization.Blood. 71:524-527. PMID:3337914

Kumar, J., Reccia, I., Kusano, T. And Agrawal, S. (2017). A Systematic Review on the Erythropoietin Receptors Expression in 
Various Cancers and Importance of Recombinant Erythropoietin in Chemotherapy Induced Anaemia. Hematol Transfus Int J. 4(1):1-6. DOI: 10.15406/htij.2017.04.00072

Langston, C., Cook, A.. Eatroff, A., Mitelberg, E. And Chalhoub S. (2017). Blood Transfusions in Dogs and Cats Receiving Hemodialysis: 230 Cases (June 1997-September 2012). J Vet Intern Med. 31(2):402-409. DOI:10.1111/jvim.14658

Langston, C.E., Reine, N.J., And Kittrell, D. (2003). The use of erythropoietin. Vet Clin North Am Small Anim Pract. 33(6):1245-1260. PMID: 14664197

Law, M.L., Cai, G.Y., Lin, F.K., Wei, Q., Huang, S.Z., Hartz, J.H., Morse, H., Lin, C. H., Jones, C. And Kao, F. T. (1986). Chromosomal assignment of the human erythropoietin gene and its DNA polymorphism. Proc Natl Acad Sci U S A. 83 (18):6920-6924. DOI: 10.1073/pnas.83.18.6920

Loughnan, A., Galil Rahman Ali, G.R. And Abeygunasekara, S.C. (2011). Comparison of the Therapeutic Efficacy of Epoetin Beta and Epoetin Alfa in Maintenance Phase Hemodialysis Patients, Renal Failure. 33 ( 3 ) : $373-375, \quad$ D O I : $10.3109 / 0886022 X .2011 .559675$

MacLeod, J.N. (2001). Clinical Trials of Recombinant $\mathrm{F}$ e $1 \mathrm{ine}$ E P O U n d e r a y. https://www.cabi.org/agbiotechnet/news/41 7

MacLeod, J.N., Tetreault, J.W., Lorschy, K.A., And Gu, D.N. (1998). Expression and bioactivity of recombinant canine erythropoietin. Am J Vet Res 59(9):1144-1148. PMID: 9736393

Mikiciuk, M.G., Polzin, D.J., And Osborne, C.A. (1990). The use of erythropoietin in chronic renal failure. Adv Small Animal Med Surg. $3: 1-3$.

Miyazaki, Y., Kuryama, K., Higuchi, H., Sohda, H., Imai, N., Saito, M., Kondo, T. And Tomonaga, M, (1997). Establishment and characterization of a new erythropoietindependent acute myeloid leukaemia cell line, AS-E2. Leukemia, 11(11): 1941-1949. DOI:

\subsection{8/sj.leu.2400838}

Oishi, A., Hamada, S., Sakamoto,H., And Shimizu, R. (1995). Preventive effects of recombinant human erythropoietin administration on anemia associated with repeated hemodialysis in nephrectomized dogs. J Vet Med Sci 57(5): 989-90. DOI: $10.1292 /$ jvms. 57.989

Peeters, H.R.M., Jongen-Lavrencic, M., Bakker, C.H., Vreugdenhil, G., Breedveld, F.C. And Swaak, A. J. G. (1999). Recombinant human erythropoietin improves health-related quality of lifein patients with rheumatoid arthritis and anaemia of chronic disease; utility measures correlate strongly with disease activity measures. Rheumatol Int. $18(5-6): \quad 201-20$. https://doi.org/10.1007/s002960050085

Qiu, H., Belanger, A., Yoon, H.P. And Bunn, H.F. (1998). Homodimerization restores biological activity to an inactive erythropoietin mutant. Journal of Biological Chemistry. 273(18): 11173-11176. doi: 10.1074/jbc.273.18.11173

Ramakrishnan, R., Cheung, W.K., Farrell, F., Joffee, L., And Jusko, W.J. (2003). Pharmacokinetic and Pharmacodynamic Modeling of Recombinant Human Erythropoietin after Intravenous and Subcutaneous Dose Administration in Cynomolgus Monkeys Journal Of Pharmacology And Experimental Therapeutics. 306 (1): 324-331.DOI: 10.1124/jpet.102.047191.

Randolph ,J.F., Stokol, T., Scarlett, J.M. And MacLeod J.N. (1999). Comparison of biological activity and safety of recombinant canine erythropoietin with that of recombinant human erythropoietin in clinically normal dogs. Am J Vet Res. 60(5):636-642. PMID:10328437

Randolph, J.F., Scarlett, J., Stokol, T. And MacLeod., J.N. (2004). Clinical Efficacy and Safety of Recombinant Canine Erythropoietin in Dogs with Anemia of Chronic Renal Failure and Dogs with Recombinant Human Erythropoietin - Induced Red Cell Aplasia. J Vet Intern Med. 18(1):81-91. https://doi.org/10.1111/j.19391676.2004.tb00139.x 
Yuartono, et. al.

Rodrigue, M.E., Brochu, I., orléans-Juste, P.D., Larivièrea, R., And Lebel, M. (2008). Effect of Erythropoietin on Blood Pressure and on the Vascular Endothelial ET-1/ETB Receptor System. Am J Hypertens. 21(6):639-643. doi:10.1038/ajh.2008.37

Sadamoto, Y., Igase, K., Sakanaka, M., Sato, K., Otsuka, H., Sakaki, S., Masuda, S. And Sasaki, R. (1998). Erythropoietin prevents place navigation disability and cortical infarction in rats with permanent occlusion of the middle cerebral artery. Biochem Biophys Res Commun 253(1):26-32. DOI: 10.1006/bbrc. 1998.9748

Sanderson, S. (2005). Use of Erythropoietin and Calcitriol for Chronic Renal Failure in Dogs and Cats. $30^{\text {th }}$ World Congress of The World Small Animal Veterinary association. May 11-14, 2005. Mexico City, Mexico

Sandhi, A. (2015). The Effect Of Erythropoietin Administration In Experimental Burns Wound Healing: An Animal Study. Thesis. Faculty Of Medicine University Of Indonesia Plastic Reconstructive And Aesthetic Surgery Study Program.

Shi., X., Yang., J., Zhu, H.,Ye, L., Feng, M., Li, J., Huang, H., Tao, Q., Ye, D., Sun, L.H.K., Sun, B.N.C., Sun, C.R.Y., Han, G., Liu, Y., Yao, M., Zhou, P. And Ju, D. ( 20013$)$. Pharmacokinetics and Pharmacodynamics of Recombinant Human EPO-Fc Fusion Protein In Vivo. PloS ONE 8(8):e72673. doi:10.1371/journal.pone. 0072673

Skibeli, V., Nissen-Lie, G. And Torjesen, P. (2001). Sugar Profiling Proves that Human Serum Erythropoietin Differs From Recombinant Human Erythropoietin. Blood. 98 (13): $3626-3632$. D O I : 10.1182/blood.V98.13.3626
Storring, P.L., Tiplady, R.J., Gaines Das, R.E., Stenning, B.E., Lamikanra, A., Rafferty, B. And Lee, J. (1998). Epoetin alfa and beta differ in their erythropoietin isoform compositions and biological properties. Br J Haematol 100 (1): 79-89. DOI: 10.1046/j.1365-2141.1998.00521.x

Surabattula, R., Sambasiva, K. R. S. And Polavarapu, R. (2011). An optimized process for expression, scale-up and purification of recombinant erythropoietin produced in Chinese hamster ovary cell culture. Research in Biotechnology. 2(3): 58-74

Tamadon, M.R. And Beladi-Mousavi, S.S. (2013). Erythropoietin; a review on current knowledge and new concepts. J Renal Inj Prev. 2(4): 119-121. D O I : $10.12861 /$ jrip. 2013.38

Toledo, J.R., Sanchez, O., Segui, R.M., Garcia, G., Montanez, M., Zamora, P.A., Rodriguez, M.P. And Cremata, J.A. (2006). High expression level of recombinant human erythropoietin in the milk of non-transgenic goats. J. Biotechnol. 123(2): 225-235. DOI: 10.1016/j.jbiotec.2005.10.019

Wen, D., Boissel, J.P., Tracy, T.E., Gruninger, R.H., Mulcahy, L.S., Czelusniak, J., Goodman, M., And Bunn, H.F. (1993). Erythropoietin Structure-Function Relationships: High Degree Of Sequence Homology Among Mammals. Blood. 82 (5):1507-1516. PMID: 8364201

Yin, H. And Blanchard, K.L. (2000). DNA methylation represses the expression of the human erythropoietin gene by two different mechanisms. Blood. 95(4): 111-119. PMID: 10607693 